\title{
The Reinforcement of Collaborative Constructive- Based Teacher Professionalism in Writing Scientific Work
}

\author{
Bambang Sumardjoko ${ }^{1}$, Harun Joko Prayitno ${ }^{2}$, Agus Prasetyo \\ \{bs131@ums.ac.id ${ }^{1}$, harun.prayitno@ums.ac.id ${ }^{2}$, a.prasetyo45@ymail.com ${ }^{3}$ \}
}

Universitas Muhammadiyah Surakarta ${ }^{1,2,3}$

\begin{abstract}
The objectives of research were: 1) to map teachers' ability of writing scientific work, 2) to explain the form of teachers' need in developing sustainable profession in scientific work writing field, and 3) to describe the collaborative constructive-based sustainable teacher profession development model to improve the scientific work writing. The research design employed was research and development one. Techniques of collecting data used were observation, in-depth interview, documentation, FGD, and questionnaire. Data analysis was conducted using qualitative and quantitative analyses. The result of research showed that firstly, teachers of SMA/MA/SMK (Senior High School) Muhammadiyah in Sukoharjo having educator certificate have not understood completely the appropriate concept of scientific work writing leading to the inadequate publication of scientific work. Teachers' experiences with writing scientific work were largely acquired when they attended Teacher Profession Training and Education. Secondly, there were many constraints in developing sustainable teacher profession. Therefore, teachers require the policy's stakeholders to simplify anything related to the incriminating administrative activity of learning, fund support, initiative of primary and secondary education chamber, access to internet network, and support from education practitioners from high education. Thirdly, a comprehensive and integrated collaborative constructivist-based sustainable teacher profession development model could improve teachers' productivity in writing scientific work. The development started with the teachers' need for writing scientific work and conducted constrictively and collaboratively, while external team gave reinforcement and facilitation.
\end{abstract}

Keywords: professionalism model, professionalism development, and scientific work.

\section{Introduction}

Teachers are professional educators with the following main duties: educating, guiding, directing, training, assessing, and evaluating students in early age child education for formal education channel, primary education, and secondary education (Law Number 14 of 2005). In education process, teachers serve not only the transfer of knowledge function but also the value inculcation and character building functions sustainably and continuously. Teachers play a very strategic part in preparing high-quality human resources with noble character. Teachers are the front guard in defining education and learning's success and quality. Therefore, many attempts should be taken to improve their professionalism continuously. 
The development of teacher professionalism builds on institution, teacher group, and teacher's needs. Danim in [1], teacher development is intended to stimulate, to maintain, and to improve the quality of staff in solving organizational problems. Teacher professionalism development is conducted through on the job training and in service training. It can be accomplished in some ways: (1) self development including functional education and training such as course, training, upgrading, and other education and training forms, (2) attending teacher workshop or work discussion group activities or in house training for teacher professionalism development activity, as keynote speaker or participants of seminar, colloquium, panel discussion or other scientific meetings, and (3) attending other collective activities corresponding to teachers' duty and obligation related to their professionalism development.

In the meantime, Castetter [2] has long suggested fives teacher development models: Individual Guided Staff Development, Observation/ Assessment, Involvement in a development/ Improvement Process, Training, and Inquiry. Out of five teacher development models, training model is the one most commonly used in private education institutions. In such education institutions, the popular method to develop teachers' professional ability is to conduct in-service training in the attempt of refreshing and upgrading, conducted either individually informally or collectively.

Meanwhile, Primary and Secondary Education Directorate General of National Education Department [3] mentions some alternatives to Teacher Professionalism Development Program as follows. (1) Teacher Education Qualification Improvement Program. (2) Equalization and Certification Program. (3) Competency-Based Integrated Training Program. (4) Education Supervision Program. (5) Subject Teacher Discussion Empowerment Program. (6) Teacher Symposium. (7) Other traditional training program. (8) Journal or scientific work reading and writing. (9) Participation in Scientific Meeting. (10) Conducting some researches (particularly Class Action Research). (11) Apprenticeship. (12) Attending Actual News from Learning Media. (13) Participation and Activeness in Professionalism Organization, and (14) Raising Cooperation along with Coworkers. Those alternative programs can be chosen as one of sustainable teacher profession development programs.

One of main issues in a sustainable teacher profession development, particularly to those with Civil Servant, is the presence of scientific work writing obligation. Meanwhile the scientific work writing ability is important to teachers (Anah Suhaenah, Kompas, April 22, 2014), because the activities during writing scientific work will be the teachers means of reflecting their experience. Data in Central Province, for example, shows that nearly $60 \%$ of Civil Servants that have achieved IVA grade can not go up to one higher grade because there is an imperative to write scientific work. Data shows that $50.88 \%$ of Secondary School teachers have occupied IVA grade but only $0.5 \%$ of them can go up to the IVB and higher grade (Yunanto, 2007). The dominant factor leading to teachers' less success in improving professionalism is teachers' poor abilities of conducting class action research and writing scientific work [4].

The writing scientific work that is published scientifically should be an important agenda and aware of by the teachers. Scientific publication should get much attention as it is the prerequisite not only for academic purpose but for the Nation's future as well. Through publishing scientific work, either scientific work in the form of research finding, review, analysis, or other scientific studies, people will know and utilize it for broader and meaningful interests. It means that the socialization and training for teachers concerning the importance of a scientific work should be conducted continuously. 
Writing scientific work, in addition to be an attempt of developing teacher profession, also serves as an attempt of improving teachers' welfare through credit point administration system corresponding to the type of scientific work type they write. Some types of scientific work the teachers can write as a means of developing their profession are: research result report, scientific review article, popular scientific writing, scientific article, textbook, and etc. All those types of scientific work can be teachers' means of developing their profession and of improving their welfare all at once. It is line with the provision included into Minister of Administrative and Bureaucratic Reform Number 16 of 2009 dated 10 November 2009 about Teachers' Functional Position and Credit Point stating that one of profession development activities is scientific publication.

Considering the description above, a sustainable teacher professionalism development model should be invented, particularly in scientific work writing. One of development models that can be conducted is the collaborative constructive-based one. The model is developed constructively, meaning that it builds on the problem found by the teachers themselves, while research team only reinforces and facilitates them. The attempt of finding solution or solving problem and writing scientific work collaborative is a foundation to develop writing ability more easily and meaningfully as it is based on the problems the teachers found themselves. This development model is expected to grow self-confidence and teachers' motivation to write scientific work.

In the mean time, the development of sustainable teacher profession in Muhammadiyah Secondary Schools in Sukoharjo, Central Java, tends to be stagnant and the teacher profession development programs have not apparently organized clearly. For that reason, a collaborative constructivist-based sustainable teacher professionalism model development is required to improve teachers' ability of writing scientific article.

Finally, the objectives of collaborative constructivist-based sustainable teacher professionalism development research to improve the scientific work writing ability are as follows: (1) to describe teachers' ability of writing scientific work, (2) to describe the form of teachers' need in developing sustainable professionalism in scientific work writing, and (3) to describe the collaborative constructivist-based teacher professionalism development model to improve the scientific work writing ability.

\section{Method}

This research and development took place in Sukoharjo Regency, Central Java Province. Data sources employed were: (1) informant consisting of teachers, headmasters, and head of chamber, (2) place/event, the learning process in school and classroom, and (3) document based on snowball sampling and purposive sampling. In the recent case, the author conducted an exploration until finding the sample actually wanted and then the author entered into the research location that has been known accurately before.

This study was a research and development, the one started with preliminary study, and then followed up with development activity through field study process, model designing, model trial, and model validation [5]. 


\section{Result and Discussion}

\subsection{Teachers' Ability of Writing Scientific Work}

The result of research showed that teachers' ability of writing scientific work in Muhammadiyah secondary school in Sukoharjo Regency still needs improvement. It can be seen from information given by some informants explained as follows. Considering the information from teachers of SMK Muhammadiyah 1 and 2 Sukoharjo (1st and 2nd Muhammadiyah Vocational High Schools of Sukoharjo), crosschecked later with informant consisting of teachers from SMA Muhammadiyah 1, 3, and SMK Muhammadiyah Watukelir, it can be concluded that there are still some constraints found in understanding scientific work concept. Teachers' experiences with writing scientific work are largely acquired when they attended Teacher Profession Education and Training. Until today, teachers still find difficulty particularly in writing and describing substantive things.

By employee status, the 119 teachers having gotten educator certificate are divided into 20 with civil servant (PNS) status, 72 Foundation's Permanent Teachers (GTY), and 27 nonpermanent teachers (GTT). By education status, they are divided into 109 with bachelor (S1) degree and 10 with master (S2) degree. By sex, they are divided into 81 females and 38 males. Teachers with educator certification's understanding on scientific work concept can be shown in the histogram below.

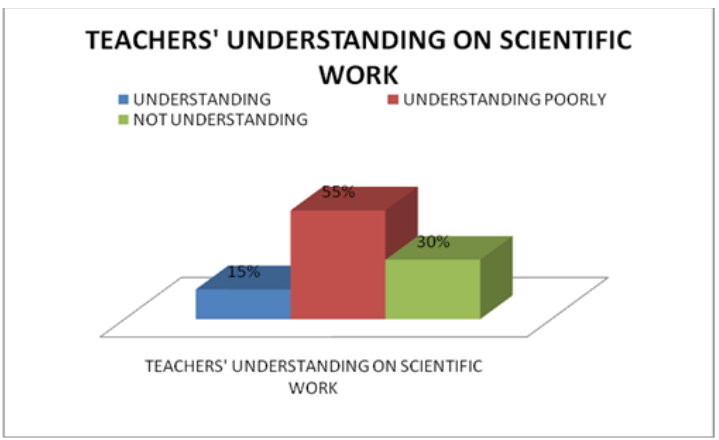

Figure 1. Certified Teachers' Understanding on Scientific Work

Figure 1 explains the teachers' understanding on the work. Only $15 \%$ of teachers really understand the scientific work writing. Such condition is in line with Sumardjoko's [4] study finding that teachers still found some constraints in writing scientific work. The constraints included: (1) low reading interest, (2) teachers' inadequate information on the recent development activity, and (3) misperception, due to inadequate information on scientific work. Then, $85 \%$ of teachers understand poorly or do not understand the scientific work writing. This data, of course, can be used to be the basis of the importance of organizing teacher training program in scientific work writing.

Scientific work is essentially a scholar's product of thinking that wants to develop science, technology, and art. This scientific activity can be accomplished through literature, experience, research, and others' previous knowledge. Scientific work, according to Pateda [6], is the product of scientific thinking in a certain discipline organized systematically, scientifically, logically, correctly, responsibly, and using right and correct language. So, scientific work is written not only to be accountable for the use of research resource (money, material, and tool) 
but also to be accountable for the scientific work writing technically and substantively. It is because the product of a scientific work is read and studied by others in infinite period of time as a means of developing science, technology, and art.

The result of scientific writing is organized logically and correctly. Therefore, to achieve the logical and correct scientism, a scientific work writer should have strong theoretical foundation to prevent the scientism featured from deviating from certain discipline and to make it accountable for. Scientific accountability is related not only to the content of scientific work but also to its writing procedure.

\subsection{The Need for Sustainable Teacher Professionalism Development}

The development of professionalism conducted by teachers in Muhammadiyah schools environment of Sukoharjo is corresponding to Guideline of Sustainable Teacher Professionalism Development. The development activity is conducted in school independently and categorized into three: (1) conducted by teachers independently, (2) in cooperation with fellow teachers in a class, and (3) through profession organization network.

The evidence of teachers' self development activity is shown by the result of interview with some informants. BS, as a Pancasila and Civic Education teacher of Vocational High School (interview on June 5, 2015), stated that "So far I have read many books, and attended workshop and outbound. If all of these can be done, these will be sufficient to improve competency in writing scientific work". This information is confirmed by a history teacher (SS), stating that "in addition to reading book, I also often browse in internet, because historical event will be found more easily in the internet. I have attended seminar and workshop as well, and all of these can support my competency as a History teacher".

The information gotten from the resource above is not different from what HS has done, as a certified teachers assuming Entrepreneurship course in SMK Muhammadiyah 1 Sukoharjo. HS developed his competency by attending seminar, workshop, and attending Subject Teacher Discussion (MGMP) activity actively. Even, there is also a teacher, ES as a Pancasila and Civic Education teacher (interview on June 8, 2015), stating that "to develop competency, in addition to attending actively MGMP activity, he also takes aside some of his income to buy laptop so that he can access internet any time, because it will helpful to searching for latest information on civic issues". ES' information was crosschecked with the information from another certified teacher in SMK Muhammadiyah 2 Sukoharjo, W, assuming physical education subject. Considering the result of interview on June 6, 2015, W said that "If the school got invitation for seminar or workshop, I always attended it. Reading book, doing physical exercise, and watching video show in Youtube are some activities I often do to improve my competency. Considering the information aforementioned, the educator-certified teachers have done some activities to develop their competency so far. They have taken many attempts to improve their professionalism sustainably as shown in the histogram below. 


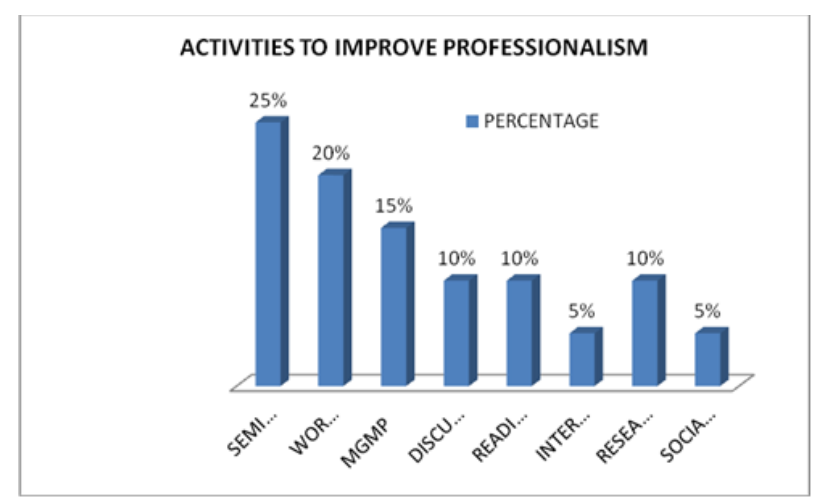

Figure 2. Teachers' Activity to Improve Professionalism

Although many attempts have been taken to develop professionalism, some problems still arise related to the sustainable teacher professionalism development. Generally, the problems arising are: limited time, limited fund, limited school infrastructure, age factor, low motivation, leader's policy, and access to internet network. Therefore, in developing their professionalism, particularly in the term of writing scientific work, teachers need (1) policy stakeholders' measures to simplify anything related to administrative activities of learning, (2) support from Primary and Secondary Education Chamber and other sponsor to give the teachers the opportunity of conducting such corresponding activities, (3) the change of policy from the Primary and Secondary Education Chamber's leader to conduct the grade increase more selectively concerning pedagogic, professional, personality, and social domains, (4) supporting access to internet network, (5) support from high education institution to the organization of workshop/seminar/and other activities, (6) supporting scholarship for advanced study.

The findings above shows that what the teachers have done in developing their professionalism independently are justifiable. It is in line with Gambell Trevor [7] stating that personal initiative to reform education based on professionalism is very important. As a professional, teachers are recommended to wrestle with the larger education objective and direction. In a more professional culture, teachers assume bigger responsibility for producing their own scientist.

\subsection{Collaborative Constructive-Based Sustainable Teacher Professionalism Development Model}

This research shows that in Muhammadiyah Primary and Secondary Education Chamber setting, teachers' ability of writing Scientific Work still needs improvement. A facilitating strategy is required in writing scientific work to teachers of SMA/MA/SMK Muhammadiyah Sukoharjo, by synergizing Muhammadiyah Primary and Secondary Education Chamber of Sukoharjo, Schools/Teachers, and High Education (Teacher Training and Education Faculty of Surakarta Muhammadiyah University). The main components supporting the organization of sustainable teacher professionalism development model in writing scientific article are as follows: (1) participation of all stakeholders, (2) Muhammadiyah Primary and Secondary Education Chamber constituting the main component determining model implementation, (3) school providing infrastructure to teachers, (4) teachers constituting the key components of model implementation, and (5) High Education as facilitator and developer.

A sustainable teacher professionalism development model is based on collaborativeconstructivism. In its implementation, it can improve the teachers' ability of writing scientific work. The model is developed constructively, meaning that the development conducted is based 
on the problems the teachers find themselves, while the research team reinforces and facilitates them. Collaborative basis means that teachers collaborate with their group (same school/same subject) to produce scientific work. The attempt of solving problem and writing scientific work collaboratively underlies the development of writing ability more easily and meaningfully as it is based on the problems found by the teachers themselves. This development model in fact can grow self-confidence and can motivate teachers to write scientific work.

This collaborative constructivism-based sustainable teacher professionalism development model to improve scientific work writing ability is as same as the training model or the learning model explained by Joyce and Weill [8]. The learning model intended consists of four categories: the social family models, the information-processing family models, the personal family models, and behavioral models [8].

The collaborative constructivism-based sustainable teacher professionalism development model for teacher in scientific work writing belongs to the social family model. It is the one focusing on the essence of human beings and learning method. This model emphasizes on community's basic characteristics, learning social behavior, and social interaction in the learning. Cooperative becomes a characteristic enhancing the quality of life, bringing about happiness and understanding on spirit, and reducing social conflict. The development of social behavior, academic skills, and knowledge products is interrelated [8]. This cooperation results in collective energy called synergy.

The information-processing family models, according to Joyce, Weil and Calhoun [8], emphasizes on improving the human character in directing the world by eliciting data, collecting data, identifying problem, finding solution to the students, developing concepts, and language to improve their ability. The information processing model is useful to themselves and community, to improve intellectual ability, and to achieve personal and social values to education.

The personal family departs from an understanding that human reality basically lies on individual consciousness. This personal model emphasizes on individual's self-development prioritizing the process of helping individual create and organizing reality, by inviting students to develop productive relation to the environment [8].

Behavioral model is based on social learning theory, behavior modification, behavior therapy, and cybernetics theories. Human beings are self correcting the communication system by reengineering behavior in responding to information successfully [8].

The effectiveness of model is evaluated for its target compatibility and achievement as specified, by comparing the professionalism before and after the model implementation. From the result of model implementation, it can be summarized as follows: (1) the model, in fact, effectively improves teachers' ability of identifying problem and formulating the theme of research constructively and collaboratively; (2) the model effectively improves the teacher group's ability of writing scientific article (constructively and collaboratively) published in national journal; and (3) the model effectively improves the sustainable teacher professionalism.

The advantages of this collaborative constructive-based development model are as follows. (1) Involving many parties in its implementation: stakeholders, Muhammdiyah Primary and Secondary Education Chamber, Schools, teachers and LPTK team. (2) Applicable using both bottom up and up to down strategies. It means that this model started with teachers' initiative, responded to and supported by Muhammadiyah Primary and Secondary Education Chamber. (3) Giving teachers the opportunity of exploring the scientific work writing as broadly as possible. It is because the model is developed constructively, based on the problems found by 
teachers themselves. (4) Giving the teachers the opportunity of identifying problem and of cooperating as broadly as possible, by which teachers will collaborated with group (same school/same subject), to produce scientific work. (5) Combining constructive and collaborative measure. (6) Involving high education practitioners as facilitator. (7) Not harming the teachers' primary job in teaching-learning process at school. It is because the school is the component of model organization so that the teachers' activity in writing scientific article will be adjusted with teaching-learning activity. (8) Having some stages conducted effectively to generate the teachers' spirit to write scientific work.

Despite some advantages aforementioned, the effectiveness of this collaborative constructive-based development model is highly dependent on the followings. (1) Teachers as the subject of model implementation; therefore teachers' motivation and willingness highly determine the effectiveness of model. (2) Teachers have conducted research and documented their report, so that they only need to follow up it by writing scientific work. (3) The publication of scientific work in ISSN or ISBN journal and National or International Proceeding needs cooperation with Muhammadiyah Primary and Secondary Education Chamber, in this case represented by teacher work group/MGMP and LPTK.

\section{Conclusion}

Firstly, in relation to scientific work writing ability, the educator-certified teachers have not understood completely yet the concept of scientific work. Teachers' experiences with writing scientific work were largely acquired when they attended Teacher Profession Training and Education. Secondly, there were many constraints in developing sustainable teacher profession. Therefore, teachers require the policy's stakeholders to simplify anything related to the incriminating administrative activity of learning, fund support, initiative of primary and secondary education chamber, access to internet network, and support from education practitioners from high education. Thirdly, a comprehensive and integrated collaborative constructivist-based sustainable teacher profession development model could improve teachers' productivity in writing scientific work. The development started with the teachers' need for writing scientific work and conducted constrictively and collaboratively, while external team gave reinforcement and facilitation.

\section{References}

[1] U. Syaefudin Sa'ud, Pengembangan Profesi Guru. Bandung: Alfabeta, 2009.

[2] W. B. Castetter, The Human Research for Educational Administration. New Jersey: A Simon \& Schuster Company, 1996.

[3] Kemendiknas, Tentang Pedoman Pengelolaan Pengembangan Keprofesian Berkelanjutan. Jakarta: Kemendiknas, 2010.

[4] B. Sumardjoko, Model Penguatan Guru Bersertifikasi melalui Pemaknaan Profesionalisme, suatu Penelitian pada Guru-guru SMA Negeri di Sukoharjo Jawa Tengah. Surakarta Indonesia: LPPM UMS, 2013.

[5] M. D. Gall, J. P. Gall, and W. R. Borg, Educational Research, An Introduction, Seventh Ed. Boston: Allyn and Bacon, 2003.

[6] M. Pateda, Bahasa Indonesia sebagai Matakuliah Dasar Umum. Flores: Nusa Indah, 1993.

[7] G. Trevor, "Teachers working around large-scale assessment: Reconstructing professionalism and professional development," 2004. [Online]. Available: https://www.researchgate.net/publication/254327405. 
[8] B. Joyce, M. Weil, and E. Calhoun, Models of teaching. New Jersey: Englewood Cliffs. Prentice-Hall Inc., 2000. 